\title{
PENGEMBANGAN MESIN KONVERTER \\ BERBASIS SISTEM TENAGA HYBRID DAN SOLAR CELL
}

\author{
Jati Widyo Leksono \\ Jurusan Teknik Elektro, Fakultas Teknik, Universitas Hasyim Asy’ary \\ Jatiwidyoleksono@gmail.com
}

\begin{abstract}
Abstrak
Pertumbuhan industri di Indonesia tidak dipungkiri semakin lama, semakin meningkat secara signifikan. Mesin konverter merupakan mesin yang telah banyak digunakan di berbagai industri maupun pabrik di Indonesia. Pada dasarnya mesin konverter menggunakan energi listik yaitu arus searah DC dan arus bolakbalik AC. Tujuan dalam penelitian ini adalah untuk mengembangkan mesin konveter dengan menggunakan sistem tenaga hybrid dan solar cell. Tenaga Hybrid umumnya merupakan penggunaan dua atau lebih suatu pembangkit listrik dengan sumber energi yang berbeda-beda. Rangkaian konverter ini mampu memperbaiki sistem distribusi kelistrikan untuk mengontrol tegangan beban untuk beban listrik statis maupun dinamis.

Kata Kunci: konverter, sistem tenaga hybrid,solar cell
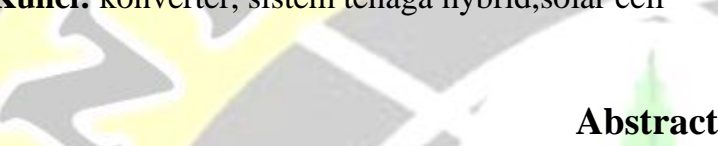

The growth of industries in Indonesia are not denied the longer, the more increased significantly. Converter is a machine the machine has been widely used in various industries as well as factories in Indonesia. Basically the engine use the energy converter listik are DC direct current and AC alternating current. Research purpose to develop a konveter machine using hybrid power system and solar cell. Hybrid power generally is the use of two or more of a power plant with different energy sources. The series of this converter is able to repair the electrical distribution system to control the voltage to load a dynamic or static electricity.
\end{abstract}

Keywords: converter, hybrid power system, solar cell

\section{PENDAHULUAN}

Indonesia merupakan negara yang mempunyai banyak keaneragaman hayati yang dapat digunakan untuk kehidupan manusia, salah satunya yaitu listrik. Saat ini listrik merupakan kebutuhan manusia yang paling penting. Hampir seluruh aktivitas manusia harus didukung oleh adanya jaringan listrik secara global. Dengan demikian, kebutuhan listrik akan terus meningkat tiap tahunnya karena ada pertumbuhan penduduk, pertumbuhan industri dan ekonomi, serta konsumsi energi listrik masyarakat yang senantiasa meningkat. Karena melonjaknya kebutuhan listrik di masyarakat, maka sistem daya tenaga alternatif harus semakin dikembangkan.

Pertumbuhan industri di Indonesia tidak dipungkiri semakin lama semakin meningkat secara signifikan. Mesin konverter merupakan mesin yang telah banyak digunakan di berbagai industri maupun pabrik di Indonesia. Pada dasarnya mesin konverter menggunakan energi listik yaitu arus searah DC dan arus bolak-balik AC. Konversi listrik ini dipengaruhi oleh suatu sirkuit disebut sebagai konverter daya. Terdapat empat konversi antara sumber DC maupun AC sebagai berikut: (1) Konverter DC - DC, yaitu dari DC menuju DC tegangan variabel; (2) Konverter DC - AC, yaitu dari DC menuju AC frekuensi variabel - satu fase / tiga fase; (3) Konverter AC - DC, yaitu dari satu fase / tiga fase menuju DC tegangan variabel; (4) Konverter $\mathrm{AC}-\mathrm{AC}$, yaitu dari satu fase / tiga fase menuju AC tegangan variabel.

Di dalam tujuan penelitian ini adalah untuk mengembangkan mesin konveter dengan menggunakan sistem tenaga hybrid dan solar cell.

Pada prinsipnya mesin konverter ini mengubah sinar matahari menjadi arus listrik searah DC. Listrik yang dihasilkan oleh sistem panel surya, sebelum masuk ke dalam jaringan distribusi dikonversi terlebih dahulu menjadi listrik AC (alternating current). Kemudian diubah kembali menjadi listrik DC (direct current). Dengan sistem hybrid menggunakan beberapa solar panel yang cukup banyak dan disambungkan baik seri maupun paralel, maka kebutuhan kabel koneksi akan berkurang karena modul surya dengan kapasitas per panel yang besar (> $100 \mathrm{Wp} /$ panel).

Tenaga Hybrid umumnya merupakan penggunaan dua atau lebih suatu pembangkit listrik dengan sumber energi yang berbeda-beda. Tujuan dari sistem tenaga hybrid pada dasarnya untuk berusaha menggabungkan dua atau lebih suatu sumber energi (sistem pembangkit listrik) sehingga 
mampu saling menutupi kelemahan masing-masing energi dan dapat mencapai tenaga maksimal, serta mampu mengefisiensi ekonomis pada beban tertentu.

\section{METODE}

Pada bagian ini merupakan tahapan rancangan pengembangan mesin konverter yang dilakukan yaiitu:
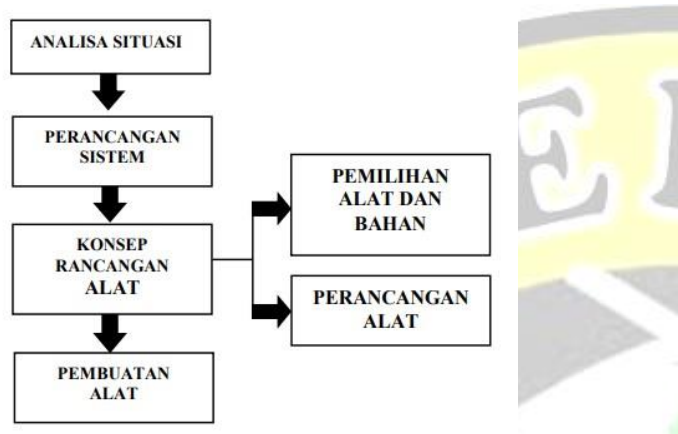

Gambar 1. Skema Tahapan Perancangan

Penelitian dan pengembangan ini melakukan analisis bersumber dari situasi lapangan dan studi literatur, serta mendefinisikan suatu kebutuhan yang dipenuhi oleh sistem yang akan dilaksanakan. Tahap berikutnya dilakukan sistem perancangan berdasarkan hasil sebelumnya. Selanjutnya, menerjemahkan suatu sistem perancangan ke dalam suatu konsep rancangan instrumen, yang selanjutnya dilakukan implementasi hasil rancangan tersebut dalam bentuk pembuatan suatu alat.

Pengembangan instrumen yang dilakukan meliputi yaitu:

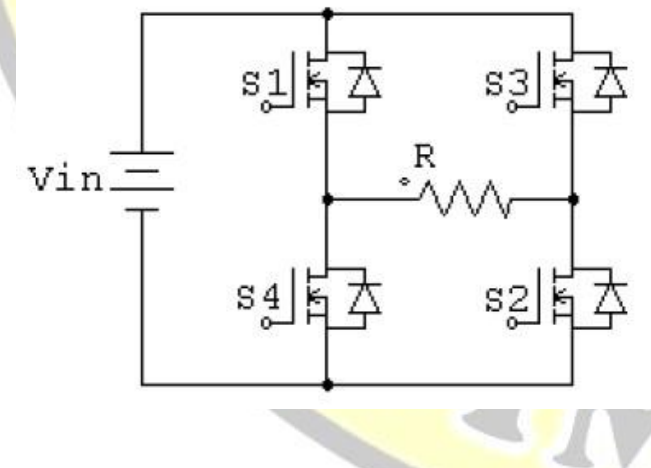

Gambar 2. Rangkaian inverter gelombang penuh

Prinsip kerja dari rangkaian di atas dapat dijelaskan dengan menggunakan 4 saklar. Bila saklar S1 dan S2 dalam keadaan ON, maka arus DC yang mengalir ke $\mathrm{R}$ dari sisi kiri ke kanan. Apabila S3 dan S4 dalam posisi ON, maka arus DC yang mengalir ke R dari sisi kanan ke kiri.
Penggunaan Solar Cell pada pengembangan instrumen yaitu:

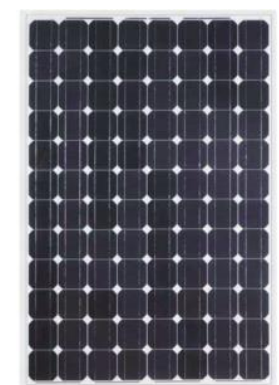

Gambar 3. Solar Cell

Solar cell yang digunakan merupakan photovoltaic (VC). Panel surya ini terbuat dari bahan semikonduktor yaitu silikon. Solar cell terdiri dari minimal 2 lapisan semikonduktor. Satu lapisan yang bermuatan positif dan lainnya mengandung muatan negatif.

Solar cell ini menangkap suatu sinar matahari yang terdiri dari partikel kecil energi foton matahari. Saat foton yang diserap telah tercukupi oleh lapisan negatif, maka elektron akan dibebaskan dari lapisan negatif ke lapisan positif sehingga menghasilkan suatu perbedaan tegangan. Terjadinya perbedaan tegangan tersebut akan mengeluarkan energi listrik yang bisa disimpan di aki.

Tegangan output dari solar cell lebih dari 12VDC (system voltage 48V 120 VDC umum dipakai). Dalam kebutuhan hal ini, BP Solar menghasilkan panel surya $130 \mathrm{Wp}$ dengan sistem voltage $24 \mathrm{~V}$.

Dalam merangkai seri atau paralel antar panel surya tersebut juga disertai dengan beberapa dioda-dioda pengaman (Bypass Diode System dan Blocking Diode System) untuk mencegah terjadinya reverse current, short circuit, dan hot spot.

Penggunaan tambahan rangkaian buck converter dalam instrumen seperti di bawah ini:

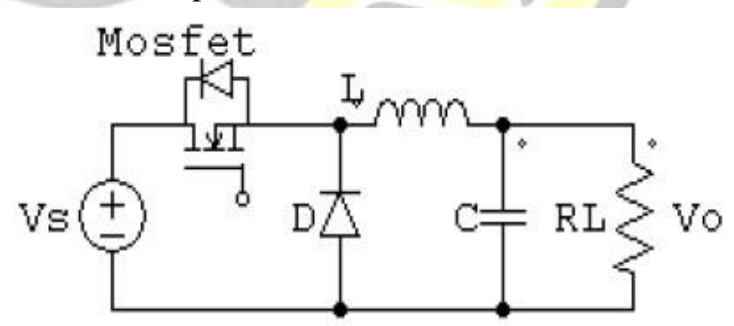

Gambar 4. Rangkaian buck converter

Dari gambar rangkaian di atas, jika kondisi saklar ON dan dioda reserve bias, arus listrik akan mengalir dari tegangan sumber VS menuju beban melewati induktor L. Apabila saklar OFF dan dioda forward bias, arus akan melaluinya. 
Penggunaan tambahan rangkaian boost converter dalam instrumen seperti di bawah ini:

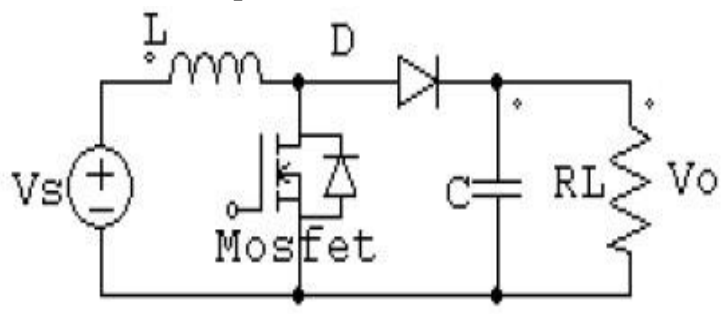

Gambar 5. Rangkaian boost converter

Pada rangkaian di atas, jika saklar MOSFET dalam posisi ON maka energi / arus listrik di induktor L akan semakin naik. Apabila saklar MOSFET dalam posisi OFF, energi / arus listrik di induktor $\mathrm{L}$ turun dan mengalir menuju beban melewati dioda. Rasio tegangan output dengan tegangan input berbanding lurus sebanding dengan rasio periode saklar ON dengan periode saklar OFF. Konverter ini mempunyai keutamaan ciri khas yang dapat menghasilkan arus input secara kontinyu.

Rangkaian Buck Converter dan Boost Converter ini meliputi: (1) PWM; (2) MOSFET; (3) Diode Freewhell; (4) Kapasitor; (5) Induktor.

Penggunaan Aki / accumulator dalam rangkaian mesin konverter seperti di bawah ini:

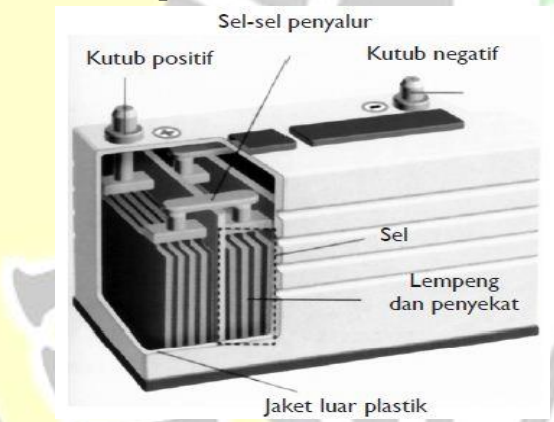

Gambar 5. Bagian-bagian accumulator

Proses pengisian accu dilakukan dengan cara memberikan tegangan input DC yang lebih besar daripada tegangan accu itu sendiri, yang mana kutup accu + dihubungkan dengan sumber DC positif dan kutup accu dihubungkan ke sumber DC negatif. Proses pengisian accu yang dilakukan terjadi perubahan dari energi listrik menjadi energi kimiawi.

\section{HASIL DAN PEMBAHASAN}

Berdasarkan perancangan rangkaian buck converter tercatat duty cycle sebesar 0,73 ; nilai induktasi sebesar $0,117 \mathrm{mH}$ serta nilai kapasitor sebesar $247,1 \mu \mathrm{F}$.

Sesuai dengan rumus persamaan yang digunakan yaitu:

$$
\text { Vout }=\mathrm{D} \times \mathrm{V} \text { in }
$$

Sedangkan pada rangkaian boost converter tercatat duty cycle sebesar 0,64; nilai induktasi sebesar $0,755 \mathrm{mH}$ serta nilai kapasitor sebesar $272,4 \mu \mathrm{F}$

Sesuai dengan rumus persamaan yang digunakan yaitu:

$$
\mathrm{D}=1-\frac{\mathrm{Vin}}{\mathrm{Vout}}
$$

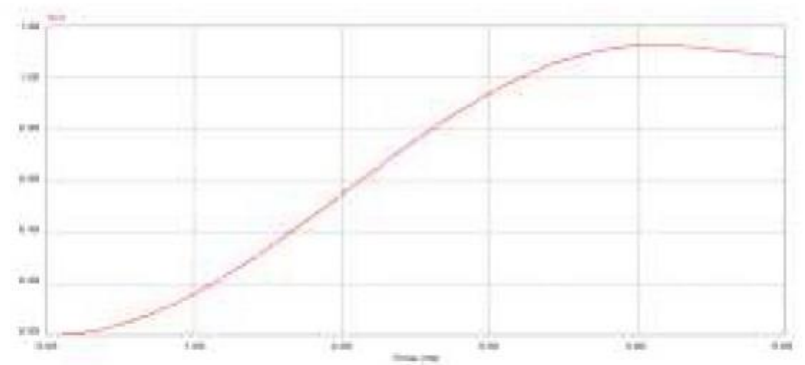

Gambar 6. Hasil Gelombang Arus Output Rangkaian buck converter

Dari gambar di atas, arus output yang muncul sebesar 5,03 ampere. Tegangan output yang dihasilkan sebesar 14,3 volt. Prosentase kesalahan antara tegangan output dengan arus output yaitu $0,95 \%$.

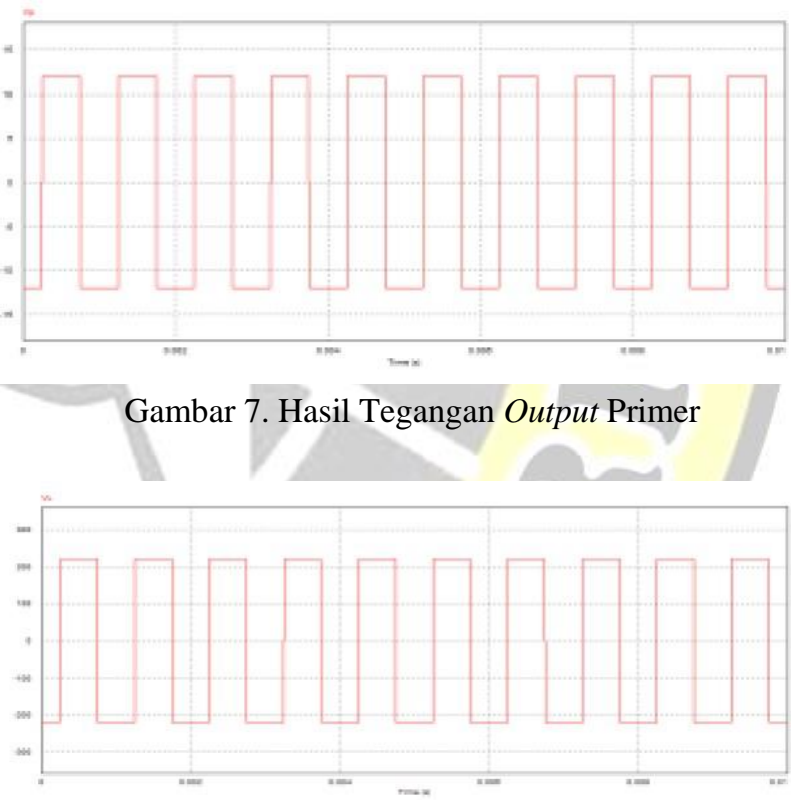

Gambar 8. Hasil Tegangan Output Sekunder

Dari hasil tegangan di atas tercatat tegangan output primer sebesar 11,89 Volt dan tegangan output sekunder sebesar 21,9 Volt. 


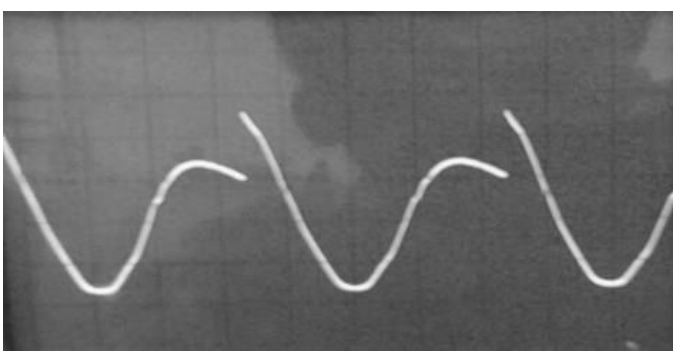

Gambar 9. Gelombang hasil dinamic load $90^{\circ}$

Hanifah, Intan Qurnia.2012. Pemanfaatan Sumber Energi Alternatif Tenaga Hybrid untuk Suplai PJU. Surabaya: PENS-ITS.

John M.Paschal.2001.EC\&M's Electrical Calculation Handbook. New York: McGrahill.

Manan Saiful. 2010. Energi Matahari Sumber Energi Alternatif yang Efisien, Handal dan Ramah Lingkungan di Indonesia. Semarang: FT Undip.

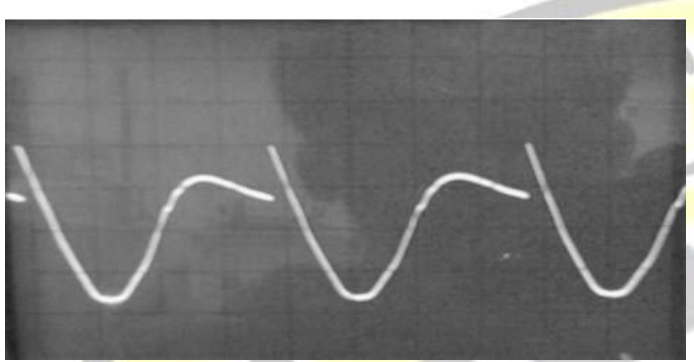

Gambar 10. Gelombang hasil dinamic load $120^{\circ}$

Berdasarkan dari data hasil penelitian di atas dengan beban listrik yang dinamis, kita dapat mengefisiensikan penggunaan listrik dengan menggunakan mesin konverter ini.

Kita dapat mengendalikan besaran tegangan output dan arus output sesuai dengan kebutuhan beban listrik sehingga penggunaan listrik akan semakin lebih efektif.

\section{PENUTUP}

\section{Simpulan}

Rangkaian konverter ini mampu memperbaiki sistem distribusi kelistrikan untuk mengontrol tegangan beban untuk beban listrik statis maupun dinamis. Hal ini tidak akan menjadikan adanya kenaikan tegangan yang signifikan karena disebabkan picuan gate yang dilakukan menggunakan thyristor.

\section{Saran}

Pengembangan mesin konverter ini masih dibatasi oleh beberapa faktor yang ada. Hal ini masih bisa dikembangkan oleh peneliti-peneliti selanjutnya yang dapat dihubungkan oleh jenis solar cell yang lebih spesifik, rangkaian tambahan converter dan inverter, atau pun dengan adanya sensor khusus.

\section{DAFTAR PUSTAKA}

D. Ding, and R.A. Cooper. 2005. Electric-Powered Wheelchairs, a review of current technology and insight into future directions. IEEE Control system Magazine, pp. 22-34.
Manjang, Salama. 2009. Pembangkit Energi Listrik Hybrid dengan Mengoptimalkan Sumber Energi Terbarukan Air dan Angin pada Remote Area di Sulawesi Selatan. Makassar: Unhas.

Rakhmawati, Renny. 2013. Pemanfaatan Sumber Energi Alternatif Tenaga Hybrid untuk Kafe Mandiri. Surabaya: Unesa Press.

Tola, Muhammad. 2013. Konverter Elektronika Daya untuk Pemakaian Tenaga Listik pada Beban Listrik Statis dan Listrik Dinamis. Makassar: Unhas Press. 